\title{
PRODUCTION AND POSTHARVEST QUALITY OF IRRIGATED PASSION FRUIT AFTER N-K FERTILIZATION ${ }^{1}$
}

\author{
DANIEL GONÇALVES DIAS², RODINEI FACCO PEGORARO ${ }^{3 *}$, \\ VICTOR MARTINS MAIA ${ }^{4}$ ANANIAS COSTA MEDEIROS ${ }^{5}$
}

\begin{abstract}
Studies with nitrogen and potassium in yellow passion fruit cultivars with high yield potential are scarce in semiarid regions. The aim of this study was to evaluate the influence the $\mathrm{N}$ and $\mathrm{K}$ doses on productivity and fruit quality of different passion fruit cultivars in irrigated conditions in the northern of Minas Gerais state. The study was installed at experimental farm located in Janaúba-MG. This area was located at $15^{\circ} 47^{\prime} \mathrm{S}$ and $43^{\circ} 18^{\prime} \mathrm{W}, 516 \mathrm{~m}$ above sea level. The experiment was in completely randomized block with four replications, arranged in $4 \times 6$ factorial design consisting of four Passion Fruit cultivars (BRS Sol do Cerrado, BRS Ouro Vermelho, BRS Gigante Amarelo, IAC 275) and six N and K doses, which corresponded to $0-0,50-125,100-250,150-375,200-500$ and 250-625 $\mathrm{kg} \mathrm{ha}^{-1} \mathrm{yr}^{-1}$ of N and $\mathrm{K}_{2} \mathrm{O}$, respectively. BRS Gigante Amarelo and BRS Sol do Cerrado cultivars showed higher productivity. Total fruit yield and average fruit weight were higher for BRS Sol do Cerrado and IAC 275, BRS Gigante Amarelo and BRS Ouro Vermelho cultivars, respectively. IAC 275 showed the highest pulp yield and along with BRS Sol do Cerrado, showed the higher soluble solids/titratable acidity ratio. BRS Sol do Cerrado, BRS Gigante Amarelo and IAC 275 cultivars showed higher pulp productivity, indicating that they are more promising for passion fruit juice industry.
\end{abstract}

Index terms: Semiarid, Cultivars, Productivity, Passiflora edulis Sims f. falvicarpa Deg.

\section{PRODUÇÃO E QUALIDADE DE FRUTOS DE MARACUJAZEIROS APÓS A ADUBAÇÃO COM NITROGÊNIO E POTÁSSIO}

\begin{abstract}
RESUMO - Estudos com doses de nitrogênio e potássio em cultivares de maracujazeiro amarelo com alto potencial produtivo são escassos nas regiões semiáridas. Objetivou-se avaliar a influência das doses de $\mathrm{N} \mathrm{e}$ $\mathrm{K}$ na produtividade e qualidade de frutos de diferentes cultivares de maracujazeiro irrigado, na região norte do Estado de Minas Gerais. O estudo foi instalado no município de Janaúba-MG e seguiu o delineamento em blocos casualizados, com quatro repetições, sendo as unidades experimentais arranjadas em esquema fatorial 4 x 6 consistindo de quatro cultivares de maracujazeiro (BRS Sol do Cerrado, BRS Ouro Vermelho, BRS Gigante Amarelo, IAC 275) e seis doses de N e K, correspondentes a 0-0, 50-125, 100-250, 150-375, 200-500 e 250-625 $\mathrm{kg} \mathrm{ha}^{-1}$ ano $^{-1}$ de $\mathrm{N}_{\text {e K}} \mathrm{O}$, respectivamente. O diâmetro médio do fruto, teor de sólidos solúveis, acidez titulável, $\mathrm{pH}$ e coloração dos frutos não apresentam diferença entre as cultivares estudadas e doses utilizadas de N e K. As cultivares BRS Gigante Amarelo e BRS Sol do Cerrado obtiveram maior produtividade. A produção total de frutos por hectare e o peso médio dos frutos foram superiores nas cultivares BRS Sol do Cerrado e IAC 275, BRS Gigante Amarelo e BRS Ouro vermelho, respectivamente. A cultivar IAC 275 teve maior rendimento em polpa e juntamente com a BRS Sol do Cerrado apresentaram maiores relações sólidos solúveis/acidez titulável. As cultivares BRS Sol do Cerrado, BRS Gigante Amarelo e IAC 275 tiveram maior produtividade de polpa, indicando serem mais promissoras para a indústria de produção de sucos de maracujá.
\end{abstract}

Termos para indexação: Semiárido, Cultivares, Produtividade, Passiflora edulis Sims f. falvicarpa Deg.

\footnotetext{
1(Paper 016-16), Received January 26, 2016. Received October 04, 2016.

${ }^{2}$ Agronomist, Master in Plant Production in the Semi-Arid, Unimontes, Avenida Reinaldo Viana, 2630, Bairro Bico da Pedra, Janaúba, MG, CEP 39.440-000. Brazil. E-mail: danielgon_d@hotmail.com

${ }^{3}$ Agronomist, D.Sc., Professor of the Instituto de Ciências Agrárias, Universidade Federal de Minas Gerais. Avenida Universitária, 1.000 - Bairro Universitário - Montes Claros - MG - CEP: 39.404-547. Brazil. *Corresponding author. E-mail: rodinei_pegoraro@yahoo.com.br ${ }^{4}$ Agronomist, D.Sc., Professor of the Department of Agrarian Sciences, Unimontes. Avenida Reinaldo Viana, 2630, Bairro Bico da Pedra, Janaúba, MG, CEP 39.440-000. Brazil. E-mail: victor.maia@unimontes.br

${ }^{5}$ Agronomist, Consórcio União da Serra Geral Company - MG. Rua Cirilo Barbosa, 380, Centro, Janauba, MG, CEP 39.440-000. Brazil E-mail: ananias.medeiros@hotmail.com
} 


\section{INTRODUCTION}

Brazil has 57,183 hectares destined to passion fruit cultivation, producing 823,284 tons of fruit and $14.5 \mathrm{t} \mathrm{ha}^{-1}$ of average yield (IBGE, 2014). The northern of Minas Gerais (Brazil) stands out for the edaphoclimatic characteristics that favor the cultivation of the passion fruit, obtaining average yields higher than national ones.

Average yield obtained in 2014 in Janauba, located in northern of Minas Gerais, was $32 \mathrm{t} \mathrm{ha}^{-1}$ (IBGE, 2014). This yield was almost twice than average values obtained for Minas Gerais state. However, according to Carvalho et al. (2000), the average Brazilian yield is still considered low, since the crop productive potential can reach 40 to $50 \mathrm{t}$ $\mathrm{ha}^{-1}$, with appropriate use of irrigation and balanced fertilization.

Main factors responsible for the low passion fruit yield are linked to use of cultivars that are unsuitable to soil and climatic conditions in planting areas (KRAUSE et al., 2012a), inadequate control of pests and diseases (AGUIAR et al., 2010) and fertilization with unbalanced doses and proportions (MENDONÇA et al., 2006).

Research and use of new passion fruit cultivars, such as the new 270 series intravarietal hybrids, produced by breeding program of "Instituto Agronômico de Campinas" (IAC) and BRS Sol do Cerrado, BRS Gigante Amarelo and BRS Ouro Vermelho cultivars from Embrapa breeding program (MELETTI, 2011) have been increased potential yield, fruit quality and resistance or tolerance to diseases and pests. However, there are few studies with these new passion fruit cultivars under irrigated conditions in the semiarid region, aiming to increase yield and fruit quality.

To increase yield of these new passion fruit cultivars, balanced fertilization is required (VENÂNCIO et al., 2013), especially with nitrogen and potassium, since these nutrients are the most uptake by the crop (ALMEIDA, 2012). Balanced fertilization with nitrogen and potassium also implies improvement of fruit physical and chemical characteristics that has been demanded by market. This demand is for fruit destined to juice agroindustry and also to fresh consumption (RODRIGUES et al., 2009).

Plant response to fertilization is more dependent on $\mathrm{N}-\mathrm{K}$ interaction than isolated use of these nutrients (MALAVOLTA et al., 1997). Nevertheless, there is a wide range of $\mathrm{N}$ and $\mathrm{K}$ doses recommended for growing and production of passion fruit. In addition, identification of yellow passion fruit cultivars that exhibit higher postharvest quality is important to increasing economic profitability of this crop. The aim of this study was to evaluate the production and physical chemical quality of fruit from different yellow passion fruit cultivars after fertilization with different $\mathrm{N}$ and $\mathrm{K}$ doses.

\section{MATERIAL AND METHODS}

The experiment was conducted from April / 2013 to April / 2014 in a Red Latosol (Oxisol), located in Janaúba-MG. Experimental area was located at $15^{\circ} 43^{\prime} 48^{\prime}$ "S and $43^{\circ} 19^{\prime}$ '24" W and $516 \mathrm{~m}$ above sea level. Local climate is classified as tropical with dry winter with average annual temperature of $25^{\circ} \mathrm{C}, 2,700$ annual hours of insolation and $65 \%$ of relative humidity (INMET, 2015).

Before passion fruit planting, the experimental area was cultivated with 'Vitória' pineapple (July 2009 to October 2011), adding approximately 20 $\mathrm{t} \mathrm{ha}^{-1}$ of organic fertilization with bovine manure, $600 \mathrm{~kg} \mathrm{ha}^{-1}$ of N, $240 \mathrm{~kg} \mathrm{ha}^{-1}$ of $\mathrm{P}_{2} \mathrm{O}_{5}$ and $800 \mathrm{~kg} \mathrm{ha}^{-1}$ of $\mathrm{K}_{2} \mathrm{O}$. At the end of this cultivation, the vegetable residues of pineapple ( $30 \mathrm{t} \mathrm{ha}^{-1}$ of dry mass) were deposited on the soil surface, remaining in rest for a period of 18 months.

Initially, experimental area was covered by pasture and weeds used as cover crops. These plants were desiccated using glyphosate to form mulch. Soil samples were collected from experimental area (0-20 and $20-40 \mathrm{~cm}$ depths) in order perform its chemical and physical characterization (TABLE 1).

According results of soil chemical and physical analysis there was no need to perform liming procedure. Subsequently, soil preparation of experimental area was carried out in a conventional way, consisting of one plowing and two harrowing in pre-planting stage.

Passion fruit cultivars seedlings were produced by sowing (two seeds per bag) in plastic bags containing $0.5 \mathrm{~L}$ of substrate and allocated in seedling nursery. Substrate was prepared in 3:1:1 proportion of soil:bovine manure:sand ratio and for each $\mathrm{m}^{3}$ of substrate. Beyond this, $5 \mathrm{~kg}$ of single superphosphate, $1 \mathrm{~kg}$ of potassium chloride, $1 \mathrm{~kg}$ of dolomitic limestone and $50 \mathrm{~g}$ of FTE-BR 12 were added. After thinning and with two months of sowing when seedlings had three pairs of full expanded leaves they were planted in experimental area.

The planting was conducted in pits with 0.4 x 0.4 x $0.4 \mathrm{~m}$, containing soil mixed with $10 \mathrm{~L}$ of bovine manure, $100 \mathrm{~g}$ of dolomitic limestone, $50 \mathrm{~g}$ of FTE-BR12 and $550 \mathrm{~g}$ of simple superphosphate. Plants were conducted in the single row system with 
spacing of $2.5 \times 2 \mathrm{~m}$, resulting in a density of 2,000 plants ha ${ }^{-1}$.

Passion fruit crop was conducted in the system of vertical espalier with a wire, being implanted at a distance of $1.70 \mathrm{~m}$ from the soil. Rows were constituted with two fence posts per row with inclination of $30^{\circ}$ and eight piles with spacing of $5 \mathrm{~m}$, totaling 20 rows in all experimental area. After planting, seedlings were conducted up to 1.80 $\mathrm{m}$, exceeding $10 \mathrm{~cm}$ from the wire. Subsequently, top pruning was performed with purpose of apical dominance breaking, thus allowing emission of two new lateral branches, which were conducted in opposite directions.

Branches were conducted to reach a length of $1 \mathrm{~m}$ on both sides. Later, top pruning of both branches was performed, also with purpose of apical dominance breaking. Then tertiaries productive branches were conducted until $40 \mathrm{~cm}$ height from the soil. During crop growing, thinning and pruning were made on stem, lateral branches and curtain to maintain them up to $40 \mathrm{~cm}$ away from the soil.

The experimental design was in completely randomized blocks with 24 treatments and three replications, with a factorial design of 4 (passion fruit cultivars $) \times 6\left(\mathrm{~N}-\mathrm{K}_{2} \mathrm{O}\right.$ doses $\left.)\right)$. This design corresponded to four yellow passion fruit cultivars (BRS Gigante Amarelo, IAC 275, BRS Ouro Vermelho and BRS Sol do Cerrado) and six N-K $\mathrm{K}_{2} \mathrm{O}$ doses (0-0, 50-125, 100-250, 150-375, 200-500 and 250-625 $\mathrm{kg} \mathrm{ha}^{-1}$ year $\left.^{-1}\right)$. Recommended mean dose (150-375 $\mathrm{kg} \mathrm{ha}^{-1}$ year $\left.^{-1}\right)$ was estimated for yield above $35 \mathrm{t} \mathrm{ha}^{-1}$ of fruit for irrigated systems, according to Sousa and Borges (2011), but with adaptations regarding split fertilization and application of fertilizers.

$\mathrm{N}$ and $\mathrm{K}$ sources used were urea, potassium chloride and potassium sulphate. Top-dressing fertilization was split in four applications between two and eight months after planting with two months intervals. For each fertilization $\mathrm{N}$ and $\mathrm{K}$ sources were diluted in $60 \mathrm{~L}$ of water and $1 \mathrm{~L}$ of this solution was applied to each plant in a range of approximately $0.2 \mathrm{~m}$ in width around the stem and distant $0.1 \mathrm{~m}$, up to 150 days after planting (DAP), increasing to $0.3 \mathrm{~m}$ from the stem, beyond $180 \mathrm{DAP}$, according to Borges et al. (2003).

Plants were irrigated by microsprinklers at $120 \mathrm{~L} \mathrm{~h}^{-1}$ flow rate arranged in 10 rows at a distance of approximately $1 \mathrm{~m}$ from the plants, totaling 10 per row. Irrigation was applied according crop needs in order to maximize mineral nutrition of plants and providing appropriate irrigation depth for each phenological crop stage.
Weed control was carried out by glyphosate application between rows at a dose of $2 \mathrm{~L} \mathrm{ha}^{-1}$, in four applications during crop cycle. Caterpillars and bugs control was performed with pyrethroid and imidacloprid, respectively, at the dose of $30 \mathrm{~mL} 100$ $\mathrm{L}^{-1}$ of water in three applications of pyrethroid and two of imidacloprid during crop cycle.

At harvesting, all fruits from three central plants of each plot were collected and characterized as following: fruit number per plot to estimate total number of fruit per hectare (thousand fruit ha-1) obtained by average number of fruit per plant times number of plants per hectare $\left(2,000\right.$ plants ha $\left.^{-1}\right)$; yield $\left(\mathrm{t} \mathrm{ha}^{-1}\right)$ and average fruit weight $(\mathrm{g})$ by yield/total fruit per hectare ratio.

Five fruits were collected per plot to determine the following physical and chemical characteristics of fruit: fruit size, length (from the peduncle base to the other end) and diameter (largest cross diameter in the equatorial portion of the fruit), skin thickness (measured at two equidistant points), in $\mathrm{cm}$; length/ diameter ratio, by dividing the length by mean fruit diameter; pulp yield, obtained by total pulp weight / total mean fruit mass ratio; pulp yield, obtained from the ratio between pulp yield and total fruit number per hectare; skin color, determined by means of Color Flex 45/0 (2200) colorimeter, stdzMode: $45 / 0$ with direct reflectance reading of coordinates $\mathrm{L} *$ (luminosity), a* (red or green hue) and $\mathrm{b} *$ (yellow and blue hue) of the Hunterlab Universal Software; soluble solids content, determined by refractometry and expressed in ${ }^{\circ}$ Brix; total titratable acidity, according to technique recommended by AOAC (2012); soluble solids/titratable acidity ratio, by dividing the percentage of soluble solids by the titratable acidity and pulp $\mathrm{pH}$.

Data were submitted to analysis of variance with F test. Scott-Knott test at 5\% significance was used to compare cultivars. Regression analysis was used to describe N-K doses effects and models were adjusted based on parameters significance and coefficient of determination, using Sisvar statistical software (FERREIRA, 2011).

\section{RESULTS AND DISCUSSION}

Fertilization with different $\mathrm{N}$ and $\mathrm{K}$ doses did not interfere $(p>0.05)$ on total fruit production and physical and chemical characteristics evaluated. However, total number of fruit per hectare, average fruit weight, yield, length, skin thickness and length / diameter ratio, pulp yield, pulp production and soluble solids/titratable acidity ratio were influenced $(\mathrm{p}<0.05)$ by yellow passion fruit cultivars. 
Total yield of fruit (fruit number) per hectare was higher in IAC 275 and BRS Sol do Cerrado cultivars in comparison to BRS Gigante Amarelo and BRS Ouro Vermelho cultivars (TABLE 2). IAC 275 produced 143 thousand fruit ha ${ }^{-1}$ more than BRS Ouro Vermelho cultivar. On the other hand, BRS Gigante Amarelo cultivar produced 51 thousand fruit $\mathrm{ha}^{-1}$ more than BRS Ouro Vermelho cultivar, which in turn presented the lowest fruit number production (TABLE 2). Total fruit production is attributed to productive characteristic of each yellow passion fruit cultivar, where genetically improved plants have greater productive potential (KRAUSE et al., 2012b).

Fruit mean weight ranged from 117.71 to 193.35 g. BRS Gigante Amarelo and BRS Ouro Vermelho cultivars presented highest mean values, with 186.73 and $193.35 \mathrm{~g}$, respectively (Table 2). These cultivars obtained an average increase of 35 and $72 \mathrm{~g}$ per fruit compared to average weights obtained by BRS Sol do Cerrado and IAC 275 cultivars, indicating that cultivars with lowest total fruit yield presented higher average fruit weight. Probably this reduction in total fruit production is due to a reduction in photoassimilates demand in function of lower number of drains in the plant. This can increase the amount of photoassimilates available to the fruits and improve photoassimilates partitioning resulting in higher fruit weight and longitudinal diameter (CRUZ et al., 2010; SILVA et al., 2009).

BRS Gigante Amarelo, BRS Ouro Vermelho and BRS Sol do Cerrado cultivars average fruit weight was considered adequate in comparison to results obtained by Meletti (2011), who found for the same cultivars average fruit weight ranging from 120 to $350 \mathrm{~g}$. Rosa et al. (2006) obtained average yellow passion fruit weight higher than $160 \mathrm{~g}$ in both $\mathrm{N}$ and $\mathrm{K}$ doses. However, IAC 275 cultivar average fruit weight and average yield obtained in this study were below $180 \mathrm{~g}$ and $48 \mathrm{tha}^{-1}$, respectively, indicated for this cultivar (MELETTI, 2001).

BRS Sol do Cerrado and BRS Gigante Amarelo cultivars presented highest fruit yield, with 45.96 and $44.89 \mathrm{tha}^{-1}$, respectively. These yield were, on average, $7.92 \mathrm{tha}^{-1}$ higher than those obtained for IAC 275 and BRS Ouro Vermelho cultivars, with 38.53 and $36.48 \mathrm{t} \mathrm{ha}^{-1}$ of fruit (TABLE 2). Yield obtained in this study are well above of national average and Minas Gerais state, that are $14.5 \mathrm{t} \mathrm{ha}^{-1}$ and 17.0 tha $^{-1}$, respectively (IBGE, 2014). This result denote the higher productive potential of yellow passion fruit cultivated under semiarid conditions especially for BRS Gigante Amarelo and BRS Sol do Cerrado cultivars.

'BRS Gigante Amarelo' cultivated in Red Latosol under irrigated conditions in Goiás state achieved $62 \mathrm{t} \mathrm{ha}^{-1}$ of fruit after 15 months of production. At same conditions BRS Ouro Vermelho and BRS Sol do Cerrado cultivars obtained productivity of 50 and $46 \mathrm{tha}^{-1}$, respectively (Vale et al., 2013).

According to classification suggested by Suassuna et al. (2011), fruit harvested in this study were classified as type "A" because average of fruit weight was above $150 \mathrm{~g}$, except for IAC 275 cultivar which was classified as type B. This cultivar showed fruit weight ranging from 100 to $150 \mathrm{~g}$. However, all harvested fruit met requirements for fresh fruit market, since consumer has preference for fruits of higher mass and good quality (SUASSUNA et al., 2011).

BRS Gigante Amarelo and BRS Ouro Vermelho cultivars obtained larger average fruit length achieving increase of $0.87 \mathrm{~cm}$ in comparison to BRS Sol do Cerrado and IAC 275 (TABLE 3). 'BRS Gigante Amarelo' also obtained the highest skin thickness $(0.60 \mathrm{~cm})$, significantly differing from the other cultivars. In contrast, IAC 275 cultivar presented lowest skin thickness, with $0.41 \mathrm{~cm}$. BRS Ouro Vermelho and BRS Sol do Cerrado cultivars showed intermediate skin thicknesses of $0.53 \mathrm{~cm}$ (TABLE 3).

General average length and diameter of fruit corresponded to $8.83 \mathrm{~cm}$ and $7.62 \mathrm{~cm}$, respectively, and were considered higher than those found by different authors (BORGES et al., 2003; BORGES et al., 2006; FORTALEZA et al., 2005). These authors obtained variations in average length and diameter of fruit from 6.50 to 7.85 and from 5.90 to $6.98 \mathrm{~cm}$, respectively. Length and diameter results observed in this study allow to conclude that those fruit have oblong characteristics, as can be observed in the relationships between length/ diameter (TABLE 3). However, BRS Gigante Amarelo and IAC 275 cultivars presented more oblong fruit, with relationships of 1.23 and 1.20, respectively, in comparison to those found in BRS Ouro Vermelho and BRS Sol do Cerrado cultivars, which corresponded to 1.18 and 1.17 , respectively.

Those characteristics described above are considered of fundamental importance for consumer market (fresh consumption and juice production), since, according to Vianna-Silva et al. (2008), fruit with large size and oblong shape with diameter greater than $7.66 \mathrm{~cm}$ and below $8.59 \mathrm{~cm}$, length higher than 9.17 and below $10.04 \mathrm{~cm}$, respectively, present juice yield of approximately $40 \%$ when 
harvested with more than $30 \%$ of yellowish skin area. Fortaleza et al. (2005) emphasize that the industry prefers oblong fruit because they present about $10 \%$ more juice than round ones.

BRS Gigante Amarelo cultivar presented average of fruit skin thickness of $0.60 \mathrm{~cm}$ being $0.06 \mathrm{~cm}$ greater than maximum skin thickness $(0.54$ $\mathrm{cm})$ reported by Fortaleza et al. (2005). BRS Sol do Cerrado and BRS Ouro Vermelho cultivars had similar skin thicknesses, but lower than those of BRS Gigante Amarelo cultivar. However, IAC 275 cultivar produced fruit with the lowest skin thickness (TABLE 3). These results corroborate those obtained by Meletti (2001), who verified skin thickness less than $0.50 \mathrm{~cm}$ for the fruit of IAC 275 cultivar.

Passion fruit skin thickness is inversely related to pulp yield, because fruit with thin skin have internal cavity with greater volume and completely filled (CAMPOS et al., 2013). Nevertheless, fruit with higher skin thickness are more suitable for transport over long distances because they reduce postharvest losses due to physical injuries (SUASSUNA et al., 2011). In the present study, as described in Table 3, IAC 275 cultivar presented the lowest mean skin thickness, which possibly provided higher pulp yield (TABLE 4), presenting an average increase of $8 \%$ when compared to the other cultivars, but did not differ significatively from BRS Gigante Amarelo, BRS Ouro Vermelho and BRS Sol do Cerrado cultivars. Krause et al. (2012a) verified that IAC 275 cultivar provided average increase in pulp yield of $4.5 \%$ more than BRS Gigante Amarelo, BRS Ouro Vermelho and BRS Sol do Cerrado cultivars. In this sense, Campos et al. (2013) showed that even though cultivars under study are of dual purpose (fresh consumption and juice production), fruit with higher pulp yield are more demanded by juice processing industries.

BRS Sol do Cerrado, BRS Gigante Amarelo and IAC 275 cultivars did not differ in relation to pulp yield. However, these cultivars were superior to BRS Ouro Vermelho cultivar, with an average increase of $5.50 \mathrm{t} \mathrm{ha}^{-1}$ (TABLE 4). This result can be attributed to fruit total number. Thus, BRS Ouro Vermelho cultivar presented smaller fruit number among studied cultivars which result in lower yield and, consequently, lower pulp yield.

Fruit total number, average fruit weight, yield, fruit length, fruit diameter, average fruit skin thickness and fruit length/diameter ratio were not influenced by fertilization with $\mathrm{N}$ and $\mathrm{K}$ doses. These averages are describe in Figure 1. One of the main justifications for this lack of N-K doses effect on passion fruit production was attributed to high nutritional contribution from residue of the previous research, since for a production of $72 \mathrm{t} \mathrm{ha}^{-1}$ of pineapple fruit, approximately, 734, 374, 120, 119, 120 and $99 \mathrm{~kg} \mathrm{ha}^{-1}$ of K, N, S, Ca, Mg and $\mathrm{P}$ were restored to the experimental area via plant residues (PEGORARO et al., 2014). This nutritional contribution from pineapple crop residue indicate the possibility of integration between passion fruit and pineapple cultivation in a crop rotation scheme in order to consider the remains of pineapple crop as an agricultural input in the management of the passion fruit fertilizer.

The present study confirms the results obtained by Rosa et al. (2006), who evaluated the effects of two $\mathrm{N}$ and $\mathrm{K}$ doses via fertigation on yellow passion fruit cultivated in consortium with dwarf coconut in northern of Rio de Janeiro state and by Venâncio et al. (2013), who evaluated the effects of increasing nitrogen doses on yellow passion fruit FB-200 cultivar in the first year of cultivation in Aquidauana-MS. The same authors attributed these results to high soil fertility and use of irrigation which increase nutrients efficiency utilization by plants. Borges et al. (2006) evaluated N doses and sources in fertigation on production and quality of yellow passion fruit in Yellow Latosol of the Coastal Table of Bahia State and verified no effect of $\mathrm{N}$ doses and sources on production, physical and chemical characteristics.

However, Bredemeier and Mundstock (2000) and Araújo et al. (2005) demonstrated N importance on metabolic functions of passion fruit, as it is present in the composition of most important biomolecules such as ATP, NADH, NADPH, chlorophyll, proteins and countless enzymes, and report $\mathrm{K}$ importance for passion fruit, as primordial nutrient during fruiting phase and fruit formation and maturation acting directly on fruit physical and chemical characteristics as well.

This lack of effect of different nitrogen and potassium doses on production and quality of passion fruit (FIGURE 2), previously reported, indicate that planting fertilization in pit with bovine manure and the initial availability (residual) of nutrients in the soil, especially $\mathrm{K}\left(156 \mathrm{mg} \mathrm{dm}^{-3}\right)$ and organic matter $\left(2.9 \mathrm{dag} \mathrm{kg}^{-1}\right.$ ), from previous cultivation (TABLE 1), supplied nutritional need for passion fruit in the first production year.

Pulp soluble solids, titratable acidity and $\mathrm{pH}$ presented average values of $13.65^{\circ} \mathrm{Brix}, 8.55 \%$ and 2.79, respectively (FIGURES 1 and 2). These averages are in accordance with maximum and minimum recommendation required by Technical Regulation for the establishment of Identification 
and Quality Standards (PIQ) for passion fruit pulp of the Brazilian Ministry of Agriculture (MAPA, 2014). This standard establishes minimum value for $11.0^{\circ}$ Brix of soluble solids content, indicating the presence of water in the product, while the minimum value required by PIQ for titratable acidity in citric acid is $2.50 \%$ and minimum and maximum $\mathrm{pH}$ value are 2.70 and 3.80 , respectively.

Soluble solids content is one of the main parameters to verify fruit pulp quality, since soluble solids include important compounds responsible for taste and consequent acceptance by consumers, being sugars and organic acids the most important. Therefore, for juice production industry and especially for fresh fruit market, high soluble solids content is a desirable characteristic. According to the industry, $11 \mathrm{~kg}$ of fruit with soluble solids content between 11 and $12^{\circ}$ Brix are necessary to obtain $1 \mathrm{~kg}$ of concentrated juice at $50^{\circ}$ Brix. Thus, it is verified that lower fruit number is required for juice concentration when these fruit present higher soluble solids content (NASCIMENTO et al., 2003).

In this sense, Santos et al. (2013) observed similar values to those of this study for soluble solids content in ripe fruit near $13.28 ; 13.00$ and $12.25^{\circ}$ Brix for BRS Gigante Amarelo, BRS Sol do Cerrado and BRS Ouro Vermelho cultivars, respectively.

Passion fruit pulp pH value (FIGURE 2) was considered within standards for fresh fruit consumption and for juice production industries (COELHO et al., 2010). However, titratable acidity content was considered above averages reported by several authors (BORGES et al., 2003; BORGES et al., 2006; SANTOS et al., 2013). This result can be attributed to the local climatic conditions and the high soil fertility, especially of organic matter, which may have contributed to the increase of $\mathrm{N}$ availability in the soil and raised the titratable acidity of fruit. According to Nascimento et al. (2003) and Ripardo (2010), sugar content and acidity of fruit may vary due to environmental factors such as temperature and solar radiation, in addition to cultural practices such as fertilizer dosages, causing direct effects on soluble solids, titratable acidity and soluble solids/ titratable acidity ratio.

Differences in soluble solids content, titratable acidity reported in different studies with yellow passion fruit may be a consequence of variability among genotypes (NASCIMENTO et al., 2003). However, high titratable acidity is not desired for fresh consumption market. However, it is desired for industries, since high acidity levels reduce the need for addition of acidifiers during processing and provides nutritional improvement, food safety and organoleptic quality (RAIMUNDO Et al., 2009). Abreu et al. (2009) evaluated five yellow passion fruit genotypes, among them BRS Gigante Amarelo, and verified titratable acidity and $\mathrm{pH}$ values of 5.57 to $8.22 \%$ and 2.96 to 3.20 , respectively, indicating the possibility of high titratable acidity values.

Highest soluble solids/titratable acidity ratios values were obtained for IAC 275 and BRS Sol do Cerrado cultivars, and these values calculated for this relationship were similar between those cultivars, providing a significant increase $(p<0.05)$ of 0.23 in comparison to BRS Gigante Amarelo and BRS Ouro Vermelho, which did not differ significantly between each other (TABLE 4). Even though there was a difference between cultivars, it was observed that soluble solids contents of fruit were higher than titratable acidity, providing ratios values of 1.76 1.74, 1.53 and 1.51 for IAC 275, BRS Sol do Cerrado, BRS Gigante Amarelo and BRS Ouro Vermelho cultivars, respectively.

Soluble solids/titratable acidity ratio presents great importance for fresh consumption market, since this characteristic is considered one of the most practical ways to evaluate fruit flavor. Titratable acidity is decisive in this characteristic promoting ratio reduction when excessively high (RAIMUNDO et al., 2009). Soluble solids/titratable acidity ratio average of passion fruit pulp observed in this study was lower than average found by different authors (BORGES et al., 2003; FORTALEZA et al., 2005; BORGES et al., 2006), who obtained ratios of 2.40 and 3.50. However, soluble solubility/titratable acidity ratios reported in the present study were close to values obtained by Abreu et al. (2009), ranging from 1.65 to 2.38 .

Fruit color at harvest time evaluated by the $\mathrm{L}^{*}, \mathrm{C} *$ and ${ }^{\circ} \mathrm{h} *$ characteristics was not influenced ( $p>0.05)$ by $\mathrm{N}$ and $\mathrm{K}$ doses, as well as by the different cultivars (FIGURE 2). However, the respective average values obtained were satisfactory being $74.18,53.74$ and $87.86^{\circ}$ for $\mathrm{L}^{*}, \mathrm{C} *$ and ${ }^{\circ} \mathrm{h}$, respectively (FIGURE 2). $\mathrm{L}^{*}$ values observed were closer to 100 which represent white, while ${ }^{\circ} \mathrm{h} *$ of $90^{\circ}$ expressed yellow color and, finally, $\mathrm{C} *$ indicates color intensity and values close to 60 express vivid colors (PINHEIRO, 2009). These results corroborate with those found by Marchi et al. (2000), who evaluated skin color of yellow passion fruit in three stages and four harvests and obtained the following results: 74 to 76,49 to 54 and 91 to $94^{\circ}$ for $\mathrm{L}^{*}, \mathrm{C} *$ and ${ }^{\circ} \mathrm{h}$, respectively, in $100 \%$ yellow fruit.

Fruit skin color results indicate an excellent potential for fresh consumption, since change in color of passion fruit skin during ripening process is 
the most used criteria by consumers to judge degree of fruit ripeness (SILVA et al., 2008). According to Boechat et al. (2010), more than $60 \%$ of Brazilian yellow passion fruit production is destined for fresh consumption (farmer markets, street markets, supermarkets, among others). The remainder is destined to juice processing industries with juice being the main product.

IAC 275, BRS Gigante Amarelo and BRS Sol do Cerrado cultivars were suitable for cultivation in edaphoclimatic conditions of semiarid region of northern of Minas Gerais state, with fruit of double suitability, indicated for both fresh consumption and industrial processing. However, IAC 275 cultivar had lower skin thickness and lighter fruit, which implies greater susceptibility to mechanical damage, especially during transportation, greatly reducing its fresh consumption. BRS Ouro Vermelho cultivar showed the lowest fruit and pulp production which may compromise its use by juice processing industries in comparison to the other cultivars studied.

TABLE 1- Chemical and physical attributes of soil samples collected at depths of 0-20 and 20-40 cm from the experimental area used in the study. Janaúba, MG. 2014.

\begin{tabular}{|c|c|c|c|c|c|c|c|c|c|c|c|c|}
\hline Depth & $\mathrm{pH}^{1}$ & $\mathrm{MO}^{2}$ & $\mathrm{P}^{3}$ & $\mathrm{~K}^{3}$ & $\mathrm{Na}^{3}$ & $\mathrm{Ca}^{4}$ & $\mathrm{Mg}^{4}$ & $\mathrm{Al}^{4}$ & $\mathrm{H}+\mathrm{Al}^{5}$ & SB & $\mathrm{t}$ & $\mathrm{T}$ \\
\hline $\mathrm{cm}$ & & dag kg-1 & \multicolumn{2}{|c|}{-- $\mathrm{mg} \mathrm{dm}^{-3}--$} & \multicolumn{8}{|c|}{ 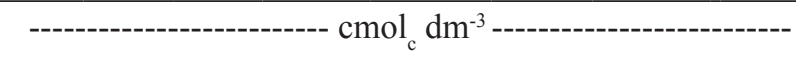 } \\
\hline $0-20$ & 5.9 & 2.9 & 3.9 & 156.0 & 0.1 & 3.0 & 1.2 & 0.0 & 1.3 & 4.7 & 4.7 & 6.0 \\
\hline $20-40$ & 5.4 & 1.4 & 3.6 & 95.0 & 0.2 & 2.6 & 0.8 & 0.0 & 1.3 & 3.8 & 3.8 & 5.1 \\
\hline Depth & $\mathrm{V}$ & $\mathrm{m}$ & $\mathrm{B}^{6}$ & $\mathrm{Cu}^{3}$ & $\mathrm{Fe}^{3}$ & $\mathrm{Mn}^{3}$ & $\mathrm{Zn}^{3}$ & P-rem ${ }^{8}$ & $\mathrm{CE}$ & Sand & Silt & Clay \\
\hline $\mathrm{cm}$ & \multicolumn{2}{|c|}{----- \% ----- } & \multicolumn{5}{|c|}{----------- mg dm³ --------- } & $\mathrm{mg} \mathrm{L}^{-1}$ & $\mathrm{dS} \mathrm{m}^{-1}$ & \multicolumn{3}{|c|}{------ dag kg-1 ----- } \\
\hline $0-20$ & 78.0 & 0.0 & 0.3 & 1.4 & 25.6 & 8.6 & 0.7 & 36.1 & 0.7 & 64 & 9 & 27 \\
\hline $20-40$ & 74.0 & 0.0 & 0.3 & 1.1 & 26.8 & 5.9 & 0.6 & 35.5 & 0.6 & 55 & 9 & 36 \\
\hline
\end{tabular}

${ }^{1} \mathrm{pH}$ in water; ${ }^{2}$ Colorimetry; ${ }^{3}$ Extractor: Mehlich-1; ${ }^{4}$ Extractor: $\mathrm{KCl} 1 \mathrm{~mol} \mathrm{~L}-1 ;{ }^{5} \mathrm{pH} \mathrm{SMP} ;{ }^{6}$ Extractor: $\mathrm{BaCl}_{2} ;{ }^{8} \mathrm{P}$ balance solution. SB, Sum of bases; t, effective CTC; T, CTC at pH 7; V, Base Saturation; m, Aluminum saturation; P-rem, remaining phosphorus; EC, Electrical conductivity.

TABLE 2 - Total number of fruits (TNF), mean fruit weight (MFW) and yield (PROD) of different yellow passion fruit cultivars in the northern state of Minas Gerais, Janaúba, MG. 2014.

\begin{tabular}{lccc}
\hline \multicolumn{1}{c}{ Cultivar } & TNF (Thousand fruits ha $\left.{ }^{-1}\right)$ & MFW $(\mathrm{g})$ & PROD $\left(\mathrm{t} \mathrm{ha}^{-1}\right)$ \\
\hline BRS Gigante Amarelo & $243.00 \mathrm{~b}$ & $186.73 \mathrm{a}$ & $44.89 \mathrm{a}$ \\
BRS Ouro Vermelho & $192.00 \mathrm{c}$ & $193.35 \mathrm{a}$ & $36.48 \mathrm{~b}$ \\
BRS Sol do cerrado & $298.00 \mathrm{a}$ & $155.11 \mathrm{~b}$ & $45.96 \mathrm{a}$ \\
IAC 275 & $335.00 \mathrm{a}$ & $117.71 \mathrm{c}$ & $38.53 \mathrm{~b}$ \\
VC (\%) & 25.11 & 10.52 & 21.91 \\
\hline
\end{tabular}

Means followed by distinct letters in the column differ from each other by the Scott-Knott's test at $(\mathrm{p} \leq 0.05)$.

TABLE 3 - Length (COF) and mean fruit diameter (MFD), mean fruit skin thickness (MST), length/diameter ratio (L/D), soluble solids content (SS), titratable acidity (TA) and $\mathrm{pH}$ of pulp of different yellow passion fruit cultivars in northern state of Minas Gerais, Janaúba. MG, 2014.

\begin{tabular}{lccccccc}
\hline \multicolumn{1}{c}{ Cultivar } & $\begin{array}{c}\text { COF } \\
(\mathrm{cm})\end{array}$ & $\begin{array}{c}\text { MFD } \\
(\mathrm{cm})\end{array}$ & $\begin{array}{l}\text { MST } \\
(\mathrm{cm})\end{array}$ & L/D & $\begin{array}{c}\text { SS } \\
\left({ }^{\circ} \text { Brix }\right)\end{array}$ & $\begin{array}{c}\text { TA } \\
(\%)\end{array}$ & $\mathrm{pH}$ \\
\hline Gigante amarelo & $9.52 \mathrm{a}$ & 7.87 & $0.60 \mathrm{a}$ & $1.23 \mathrm{a}$ & 13.41 & 8.71 & 2.80 \\
Ouro Vermelho & $9.28 \mathrm{a}$ & 7.91 & $0.52 \mathrm{~b}$ & $1.18 \mathrm{~b}$ & 13.37 & 8.81 & 2.76 \\
Sol do cerrado & $8.18 \mathrm{~b}$ & 7.82 & $0.54 \mathrm{~b}$ & $1.17 \mathrm{~b}$ & 13.82 & 8.52 & 2.82 \\
IAC 275 & $8.29 \mathrm{~b}$ & 6.89 & $0.41 \mathrm{c}$ & $1.20 \mathrm{a}$ & 14.00 & 8.17 & 2.79 \\
VC (\%) & 6.27 & 12.31 & 14.10 & 3.78 & 8.40 & 11.22 & 5.52 \\
\hline
\end{tabular}

Means followed by distinct letters in the column differ from each other by the Scott-Knott's test at $(\mathrm{p} \leq 0.05)$. 
TABLE 4 - Pulp yield (yield), pulp production (production), soluble solids/titratable acidity ratio (SS/TA), luminosity $\left(\mathrm{L}^{*}\right)$, chromaticity $\left(\mathrm{C}^{*}\right)$, hue angle of fruits $\left({ }^{\circ} \mathrm{h}^{*}\right)$ of different cultivars in northern state of Minas Gerais, Janaúba, MG, Brazil.

\begin{tabular}{|c|c|c|c|c|c|c|}
\hline Cultivar & Yield (\%) & $\begin{array}{c}\text { Production } \\
\left(\mathrm{t} \mathrm{ha}^{-1}\right)\end{array}$ & $\mathrm{SS} / \mathrm{TA}$ & $\mathrm{L}^{*}$ & $\mathrm{C}^{*}$ & ${ }^{\circ} \mathrm{h}^{*}$ \\
\hline Gigante amarelo & $52.68 \mathrm{~b}$ & $23.94 \mathrm{a}$ & $1.53 \mathrm{~b}$ & 73.51 & 53.24 & 88.84 \\
\hline Ouro Vermelho & $50.11 \mathrm{~b}$ & $18.38 \mathrm{~b}$ & $1.51 \mathrm{~b}$ & 73.95 & 53.54 & 87.47 \\
\hline Sol do cerrado & $53.74 \mathrm{~b}$ & $24.53 \mathrm{a}$ & $1.74 \mathrm{a}$ & 75.51 & 53.84 & 87.25 \\
\hline IAC 275 & $60.17 \mathrm{a}$ & $23.17 \mathrm{a}$ & $1.76 \mathrm{a}$ & 73.74 & 54.33 & 87.87 \\
\hline $\mathrm{VC}(\%)$ & 9.26 & 25.10 & 17.93 & 5.57 & 5.53 & 2.65 \\
\hline
\end{tabular}

Means followed by distinct letters in the column differ from each other by the Scott-Knott's test at $(\mathrm{p} \leq 0.05)$.

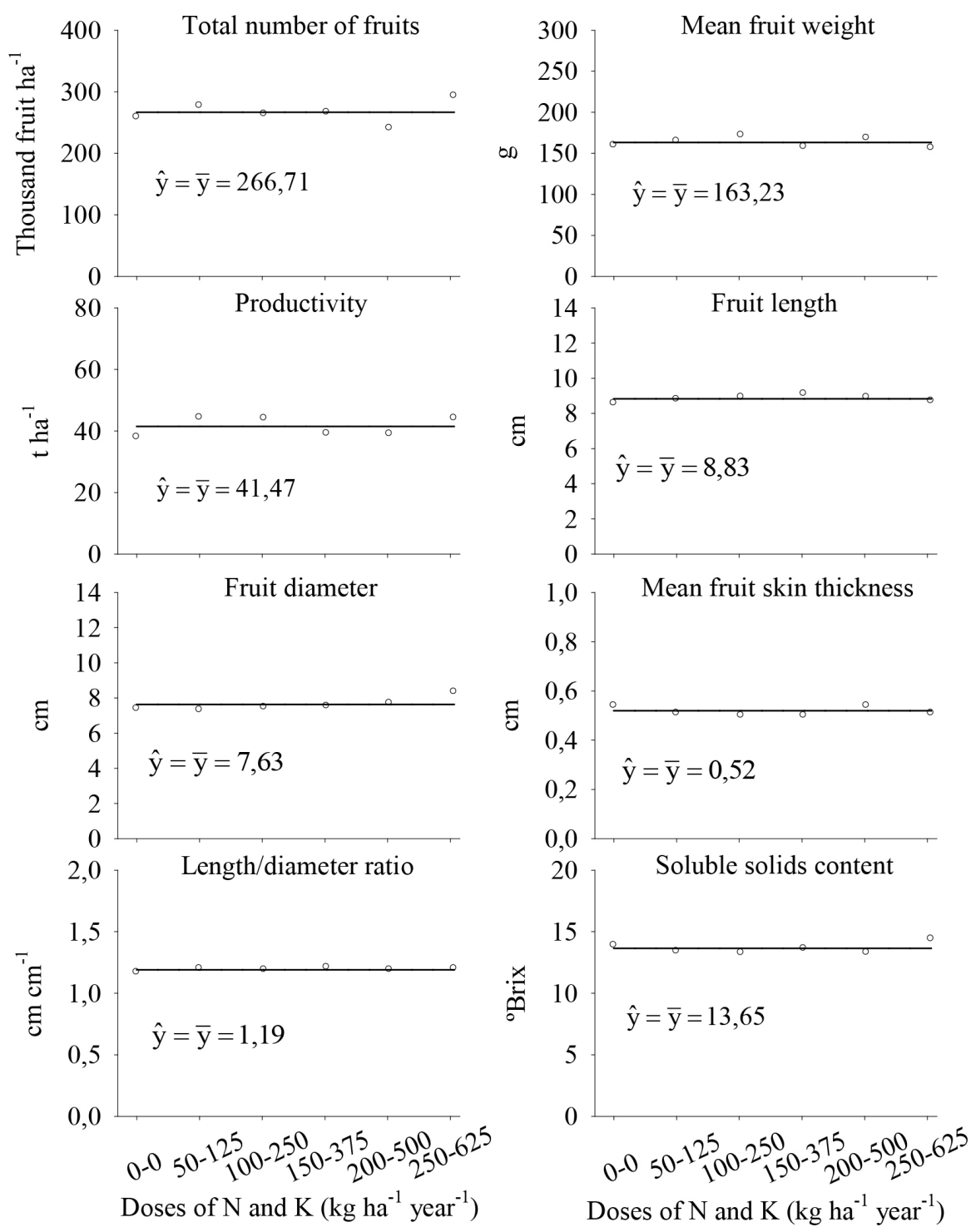

FIGURE 1 - Total number of fruits, mean fruit weight, productivity, fruit length and diameter, mean fruit skin thickness, length/diameter ratio (L/D) and soluble solids content for yellow passion fruits after nitrogen and potassium fertilization with increasing recommendation percentages $(\mathrm{N}-\mathrm{K}$ percentage) in northern state of Minas Gerais, Janaúba, MG, 2014. 


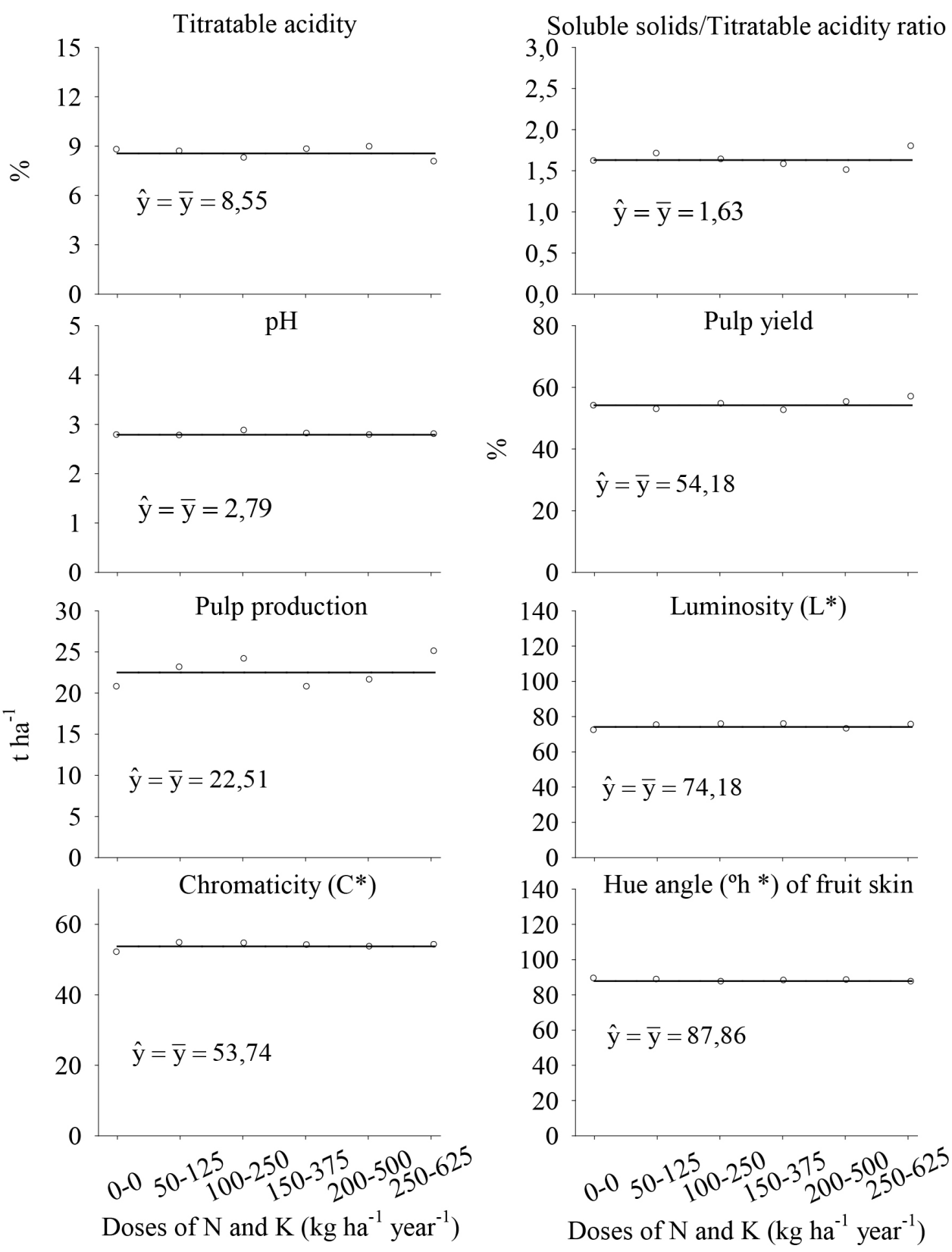

FIGURE 2 - Titratable acidity, soluble solids / titratable acidity ratio, $\mathrm{pH}$, pulp yield, pulp production, luminosity $(\mathrm{L} *)$, chromaticity $(\mathrm{C} *)$ and hue angle $\left({ }^{\circ} \mathrm{h} *\right)$ of fruit skin for yellow passion fruits submitted to different N-K doses (N-K percentage) in northern state of Minas Gerais, Janaúba, MG, 2014. 


\section{CONCLUSIONS}

$\mathrm{N}$ and $\mathrm{K}$ fertilization did not influence production and quality of yellow passion fruit in Janaúba-MG.

BRS Gigante Amarelo and BRS Sol do Cerrado cultivars showed higher yields, and BRS Sol do Cerrado and IAC 275 cultivars showed higher total fruit yield per hectare and average fruit weight.

BRS Gigante Amarelo cultivar had higher average fruit skin thickness and considering average fruit length showed the highest values with BRS Ouro Vermelho as well.

BRS Sol do Cerrado, BRS Gigante Amarelo and IAC 275 cultivars showed higher pulp yield.

\section{ACKNOWLEDGMENTS}

The authors thank the Foundation for Research Support of Minas Gerais (FAPEMIG), National Council for Scientific and Technological Development (CNPq) and Pro-Rectory Research of Federal University de Minas Gerais (PRPq-UFMG) for financial and scholarship support. We also thank the CNPq for the Research Productivity Grant to the second and third author.

\section{REFERENCES}

ABREU, S.P.M.; PEIXOTO, J.R.; JUNQUEIRA, N.T.V.; SOUZA, M. A.F. Características físicoquímicas de cinco genótipos de maracujazeiro-azedo cultivados no Distrito Federal. Revista Brasileira de Fruticultura, Jaboticabal, v.31, n.2, p.487-491, 2009.

AGUIAR, A.V.M.; SILVA, R.M.; CARDOSO, E.A.; MARACAJÁ, P.B.; PIRES, H.G. Utilização de espécies de Passiflora spp. como porta-enxertos no controle de doenças do maracujazeiro. Agropecuária Científica no Semi-Árido, Patos, v.6, n.4, p.17-22, 2010.

ALMEIDA, R.F. de, Nutrição de Maracujazeiro. Revista Verde de Agroecologia e Desenvolvimento Sustentável, Mossoró, v.7, n.3, p. 12-17, 2012.

AOAC - Association Of Official Analytical Chemistry. Official methods of analysis of AOAC International. $19^{\text {th }}$ ed. Gaithersburg: AOAC International, 2012.3000p.
ARAÚJO, R.C.; BRUCKNER, C.H.; MARTINEZ H.E.P.M.; SALOMÃO L.C.H.; VENEGAS V.H.A.V.; DIAS J.M.M.; PEREIRA W.E.; SOUZA J.A. Crescimento e produção do maracujazeiro-amarelo em resposta à nutrição potássica. Revista Brasileira de Fruticultura, Jaboticabal, v.27, n.1, p.128-131, 2005.

BOECHAT, C.L.; TEIXEIRA, A.M.; COSTAA.S.V.; SOUZAA.P.S.B. Influência de substratos associados à adubação mineral sobre o crescimento inicial de duas cultivares de maracujazeiro-amarelo. Revista Caatinga, Mossoró, v.23, n.3, p. 19-25, 2010.

BORGES, A.L.; CALDAS, R.C.; LIMA, A.A. Doses e fontes de nitrogênio em fertirrigação no cultivo do maracujá-amarelo. Revista Brasileira de Fruticultura, Jaboticabal, v.28, n.2, p. 301-304, 2006.

BORGES, A.L.; RODRIGUES M.G.V.; LIMAA.A.; ALMEIDA I.E.; CALDAS R.C. Produtividade e qualidade de Maracujá-Amarelo irrigado, adubado com Nitrogênio e Potássio. Revista Brasileira de Fruticultura, Jaboticabal, v.25, n.2, p. 259-262, 2003.

BREDEMEIER, C.; MUNDSTOCK, C.M. Regulação da absorção e assimilação do nitrogênio nas plantas. Ciência Rural, Santa Maria, v.30, n.2, p. $365-372,2000$.

CAMPOS, V.B.; FOGAÇA T.S.; ALMEIDA W.L.; BARBOSA J.A.; OLIVEIRA M.R.T.; GONDIM S.C.; CAVALCANTE L.F. Caracterização física e química de frutos de maracujá-amarelo comercializados em Macapá, Amapá. Revista Brasileira de Produtos Agroindustriais, Campina Grande, v.15, n.1, p.27-33, 2013.

CARVALHO, A.J.C.; MARTINS D.P.; MONNERAT P.H.; BERNARDO S. Adubação nitrogenada e irrigação no maracujazeiro-amarelo. I Produtividade e qualidade dos frutos. Pesquisa Agropecuária Brasileira, Brasília, DF, v.35, n.6, p.1101-1108, 2000.

COELHO, A.A.; CENCI, S.A.; RESENDE, E.D. Qualidade do suco de maracujá-amarelo em diferentes pontos de colheita e após o amadurecimento. Ciência e Agrotecnologia, Lavras, v.34, n.3, p. 722-729, 2010 . 
CRUZ, M.C.M.; RAMOS J.D.; MOREIRA R.A.; SANTOS V.A. dos. Crescimento de tangerinas 'Ponkan' em plantas submetidas ao raleio químico. Revista Ceres, Viçosa, MG, v.57, n.4, p. 500-505, 2010.

FERREIRA, D.F. Sisvar: a computer statistical analysis system. Ciência e Agrotecnologia, Lavras, v.35, n.6, p. 1039-1042, 2011.

FORTALEZA, J. M.; PEIXOTO J.R.; JUNQUEIRA N.T.V; OLIVEIRA A.T.; RANGEL L.E.P. Características físicas e químicas em nove genótipos de maracujá azedo cultivado sob três níveis de adubação potássica. Revista Brasileira de Fruticultura, Jaboticabal, v.27, n.1, p. 124-127, 2005.

IBGE - Instituto Brasileiro de Geografia e Estatística. Produção agrícola municipal: Informações sobre culturas permanentes. 2014. Disponível em: $<\mathrm{http} / /$ www.sidra.ibge.gov.br/bda/pesquisas/pam $/>$. Acesso em: 13 set. 2016.

INMET - Instituto Nacional de Meteorologia. Dados históricos. 2015. Disponível em: <http://www. inmet.gov.br/projetos/rede/pesquisa/gera serie txt mensal. php $>$. Acesso em: 05 jun. 2015.

KRAUSE, W.; NEVES L.G.; VIANAA.P.; ARAÚJO C.A.T.; FALEIRO F.G. Produtividade e qualidade de frutos de cultivares de maracujazeiro-amarelo com ou sem polinização artificial. Pesquisa Agropecuária Brasileira, Brasília, DF, v.47, n.12, p.1737-1742, 2012a.

KRAUSE, W.; SOUZA, R.S.; NEVES, L.G.; CARVALHO, M.L.S.; VIANA, A.P.; FALEIRO, F.G Ganho de seleção no melhoramento genético intrapopulacional do maracujazeiro-amarelo. Pesquisa Agropecuária Brasileira, Brasília, DF, v.47, n.1, p.51-57, 2012 b.

MALAVOLTA, E.; VITTI, G.C.; OLIVEIRA, S.A. Avaliação do estado nutricional das plantas: princípios e aplicações. Piracicaba: Potafos, 1997. 308p.
MAPA - Ministério da Agricultura, Pecuária e do Abastecimento. Regulamento técnico para fixação dos padrões de identidade e qualidade para polpa de maracujá. Disponível em: $\leq \mathrm{http}: / /$ www.redejucara.org.br/legislacao/IN01_00-MAPA

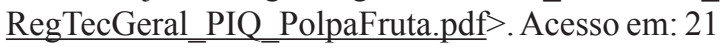
jun.2014.

MARCHI, R.; MONTEIRO. M.; BENATO E.A.; SILVA C.A.R. Uso da cor da casca como indicador de qualidade do maracujá amarelo (Passiflora edulis Sims. f. flavicarpa Deg.) destinado à industrialização. Ciência e Tecnologia de Alimentos, Campinas, v.20, n.3, p.381-387, 2000.

MELETTI, L.M.M. Avanços na cultura do maracujá no Brasil. Revista Brasileira de Fruticultura, Jaboticabal, v.33, n.1, p.83-091, 2011. Volume especial

MELETTI, L.M.M. Maracujá-amarelo: cultivares IAC conquistam a preferência nacional. O Agronômico, Campinas, v.53, n.2, p.23-25, 2001.(1)

MENDONÇA, V.; NETO S.E.A.; RAMOS J.D.; CARVALHO J. G.; ANDRADE JUNIOR, V.C. Fontes e doses de fósforo para o maracujazeiroamarelo. Revista Caatinga, Mossoró, v.19, n.1, p.65-70, 2006.

NASCIMENTO, W.M.O.; TOMÉ, A.T.; OLIVEIRA, M.S.P. Seleção de progênies de maracujazeiroamarelo (Passiflora edulis f. flavicarpa) quanto à qualidade de frutos. Revista Brasileira de Fruticultura, Jaboticabal, v.25, n.1, p. 186-188, 2003.

PEGORARO, R.F.; SOUZA, B.A.M.; MAIA, V.M.; SILVA, D.F.; MEDEIROS A.C.; SAMPAIO R.A. Macronutrient uptake, accumulation and export by the irrigated 'vitória' pineapple plant. Revista Brasileira de Ciência do Solo, Viçosa, v.38, n.3, p. 896-904, 2014.

PINHEIRO, J.M. da S. Tecnologia pós-colheita para conservação de bananas dacultivar Tropical. 2009. 59 f. Dissertação (Mestrado em Produção Vegetal no Semiárido) - Universidade Estadual de Montes Claros, Janaúba, 2009. 
RAIMUNDO, K.; MAGRI R.S.; SIMIONATO E.M.R.S.; SAMPAIO R.S. Avaliação física e química da polpa de maracujá congelada comercializada na região de bauru. Revista Brasileira de Fruticultura, Jaboticabal, v.31, n.2, p. 539-543, 2009.

RIPARDO, A.K.S. da. Doses de NPK no desenvolvimento, produtividade e qualidade de frutos do maracujazeiro 'Roxinho do Kênia'. 2010. 71 f. Dissertação (Mestrado) - Universidade Estadual Paulista, Faculdade de Ciências Agronômicas, Botucatu, 2010.

RODRIGUES, A.C.; CAVALCANTE L.F.; OLIVEIRA A.P.; SOUZA J.T.; MESQUITA F.O. Produção e nutrição mineral do maracujazeiroamarelo em solo com biofertilizante supermagro e potássio. Revista Brasileira Engenharia Agrícola Ambiental, Campina Grande, v.13, n.2, p.117-124, 2009.

ROSA, R.C.C.; MONNERAT P.H.; SANTOS A.L.; PIRES A.A.; PINHO L.G.R.; MARTINS A.O. Doses de nitrogênio e potássio em fertirrigação em maracujazeiro amarelo consorciado com coqueiroanão verde, na região Norte Fluminense. Revista Brasileira de Fruticultura, Jaboticabal, v.28, n.1, p. 113-116, 2006.

SANTOS, J.L.V.dos.; RESENDE E.D. de.; MARTINS D.R.; GRAVINA, G.A.; CENCI S.A.; MALDONADO J.F.M. Determinação do ponto de colheita de diferentes cultivares de maracujá. Revista Brasileira de Engenharia Agrícola e Ambiental, Campina Grande, v.17, n.7, p.750-755, 2013.

SILVA, L.C.; RUFATO L.; KRETZSCHMAN A.A.; MARCON FILHO L.L. Raleio de cachos em vinhedos de altitude e qualidade do vinho da cultivar Syrah. Pesquisa Agropecuária Brasileira, Brasília, DF, v.44, n.2, p.148-154, 2009.

SILVA, T.V.; RESENDE E.D.; VIANA A.P.; PEREIRA, S.M.F.; CARLOS, L.A.; VITORAZI, L. Determinação da escala de coloração da casca e do rendimento em suco do maracujá-amarelo em diferentes épocas de colheita. Revista Brasileira de Fruticultura, Jaboticabal, v.30, n.4, p. 880-884, 2008.
SOUSA, V.F.; BORGES, A. L. Irrigação e fertirrigação na cultura do maracujá. In: SOUSA, V.F.; MAROUELLI, W. A.; COELHO, E. F.; PINTO, J. M.; COELHO FILHO, M. A. (Ed.). Irrigação e fertirrigação em fruteiras e hortaliças. Brasília, DF: Embrapa Informação Tecnológica, 2011. cap. 17, p. 501-522.

SOUZA, M.; GUIMARÃES, P.T.G.; CARVALHO, J.G.; FRAGOAS, J.C. Maracujazeiro. In: RIBEIRO, A.C.; GUIMARÃES, P.T.G.: ALVAREZ V., V.H. (Ed.). Recomendação para o uso de corretivos e feritlizantes em Minas Gerais: $5^{\mathrm{a}}$ aproximação. Viçosa: Comissão de Fertilidade do solo de Minas Gerais, 1999. p.242-243.

SUASSUNA, J.F.; MELO, A.S.; FERRAZ, R.L.S.; PEREIRA, V.M.; SOUZA, M.S.S. Rendimento e qualidade da produção de híbrido de maracujazeiroamarelo 'IAC 273/277' sob diferentes níveis de irrigação. Revista Caatinga, Mossoró, v.24, n.4, p.115-122, 2011.

VALE, L.S.R.; MATOS, G.R.; SOARES, R.S.; SILVA, J.K.R.M. Desempenho agronômico de cultivares de maracujazeiro híbrido. Global Science and Technology, Rio Verde, v.6, n.3, p.178-183, 2013.

VENÂNCIO, J.B.; RODRIGUES, E.T.; SILVEIRA, M.V.; ARAÚJO, W.F.; CHAGAS, E.A.; CASTRO, A.M. Produção, qualidade dos frutos e teores de nitrogênio foliar em maracujazeiro-amarelo sob adubação nitrogenada. Científica, Jaboticabal, v.41, n.1, p.11-20, 2013.

VIANNA-SILVA, H.; RESENDE, E.D.; PEREIRA, S.M.F.; VIANA, A.P.; ROSA, R.C.C.; CARLOS, L.A.; VITORAZI, L. Influência dos estádios de maturação sobre as características físicas dos frutos de maracujá-amarelo. Bragantia, Campinas, v.67, n.2, p.521-525, 2008. 